\title{
Exploring the Determinants Attractiveness to Foreign Direct Investments: Do Public Governance, Infrastructure and Macroeconomic Policies Matter?
}

\author{
Adel BOGARI
}

Correspondence: Assistant Professor- College of Business Administration, Al-Baha University, KSA

Received: June 12, 2021 Accepted: July 29, 2021 Online Published: August 20, 2021

doi:10.5539/res.v13n3p63 URL: https://doi.org/10.5539/res.v13n3p63

\begin{abstract}
The aim of this paper is to determine the factors that attract Foreign Direct Investments (FDIs) to Central and Eastern European Countries (CEECs) and Southern and Eastern Mediterranean Countries (SEMCs). To this end, this paper tested three variables representing public governance, physical infrastructure and macroeconomic quality, over a ten-year period stretching from 2008 to 2017. The results of the regressions estimated on CEE countries show that entrepreneurs are attracted to this region mainly for governance and infrastructure quality. Macroeconomic policy variables seem to attract less FDIs to these countries. Using aggregated variables, the results of the regressions estimated on SEMCs show that the governance variable becomes statistically significant but retains a low value. The other variables of physical infrastructure and macroeconomic policies seem to be more robust and better explain FDI inflows to this region.
\end{abstract}

Keywords: FDIs, public governance, physical infrastructure, macroeconomic policies

\section{Introduction}

Foreign direct investment (FDI) is a very complex phenomenon to be empirically measured. FDI inflows are international transfers of financial capital with the aim of expanding or acquiring foreign businesses. The idea of being able to uphold the long-term management of a foreign company is very challenging as suggested by the International Monetary Fund (IMF) and the Organization for Economic Co-operation and Development (OECD), and justifies the difficulties in measuring FDIs because of their qualitative dimension.

FDIs are three types: 1) direct investment capital, 2) intra-group loans (between parent companies and their subsidiaries), and 3) retained earnings that are reinvested by subsidiaries abroad. In general, FDIs should be at least $10 \%$ of the equity capital of the invested firm.

The growing importance of FDI inflows and the key roles increasingly allocated to multinational companies (MNCs) in the global landscape continue to attract the interest of economists and politicians. Non-governmental organizations have recommended and proposed agendas for States, particularly developing and transition countries, to attract this type of foreign capital.

The sociopolitical context of a country helps to define its investment climate and thus contributes to the creation of favorable conditions for economic growth. Recent theoretical and empirical contributions show that differences in growth and productivity between countries closely bear on the differences between their political, institutional and legal contexts (Hall \&Jones, 1999; Keefer \& Knack, 1997; Knack \& Keefer, 1995; Kaufman et al. 1999). Moreover, foreign direct investment has been shown to promote efficiency of the host country. Examining the impact of macro-governance on FDI inflows across countries is a natural extension of this line of research. The determinants of FDIs should not only target firm-specific features but also the country's macroeconomic outlook. Attempts to focus exclusively on economic factors have generally led to unsatisfactory outcomes and at best partially explained this phenomenon.

This paper therefore focuses on the relationship between foreign direct investment inflows and public governance in Central and Eastern European Countries (CEECs) ${ }^{1}$ and Southern and Eastern Mediterranean Countries (SEMCs) ${ }^{2}$.

The rest of the paper is organized as follows: Section tow briefly reviews the relevant theoretical background. Section three displays the methodology, the sample and the study period. Section four presents the empirical findings. Finally,

\footnotetext{
${ }^{1}$ Central and Eastern European countries include 11 States: Bulgaria, Croatia, Estonia, Hungary, Czech Republic, Estonia, Lithuania, Poland, Romania, Slovenia, Slovakia. Latvia is not part of the Central and Eastern European countries because of luck of data.

${ }^{2}$ South and East Mediterranean countries include 5 States: Egypt, Jordan, Lebanon, Morocco and Tunisia. Algeria, Libya, Israel, and Syria are not part of the South and East Mediterranean countries because of luck of data.
} 
section five concludes.

\section{Theoretical Background}

Until the 1990s, behavior of developing countries towards foreign companies was suspicious. Globalization had contributed to a fundamental change in the attitude of these countries towards foreign investors and had made all countries seek to enhance their potential attractiveness. In this new context, the pressure exerted by foreign companies on host countries is stronger and competition between countries is increasingly strong, prompting the latter to establish attractive policies to meet the increasingly selective needs of foreign investors.

In what follows we recall the determinants of the globalization of firms by presenting the theories behind foreign direct investments. The theoretical approaches to study this phenomenon are many; they include countries' macroeconomic features and firms' microeconomic dimensions.

From a macroeconomic point of view, FDIs are considered to be international capital movements motivated by differences in the cost of capital. Kojima (1973) consider FDIs as transfers of technology and managerial know-how, which in combination with the advantages inherent in the location of the host country give the firm a higher return compared to its home country. Although an ageing process may appear, Aliber's (1970) theory of currency zones remains interesting from a historical perspective. Countries with strong currencies appear as sources of FDIs, while countries with weak currencies appear as host territories.

The theory of oligopolistic behavior of firms, which highlights the advantages of a hosting monopoly, represents a considerable account that convincingly explains international production. A breakthrough came with Hymer (1960). For the first time, it is suggested that FDIs are motivated by the advantage of controlling related foreign activities where market imperfections prevail. Kindlebefger (1969) and Caves (1971) develop Hymer's ideas. Caves insists that a differentiated oligopolistic market structure particularly leads to the emergence and development of multinational corporations. In the same line of thinking, Buckley \& Casson (1976) insist on the internalization of skills and knowledge as driving forces behind the development of multinationals since the end of World War II. Dunning (1981) integrates the firm's approach with domestic macroeconomic indicators, while Hirsh (1976) formulates the trade-off between export and foreign production and sets the conditions under which either method serving the foreign market is more profitable. Knickerbocker's (1976) study of the oligopolistic reactions of firms tries to explain why FDIs are concentrated in time and space. While providing a partial explanation as well, the product life cycle theory retains some validity. In his paper (1966), Vernon formulates a proposal to explain trade referring to the characteristics of the product offer. Trade results from innovation in rich countries that constantly create new goods, initially expensive for their domestic market. The growth of local demand favors mass production, reducing average production costs, and then favors exports abroad. Once the product is commoditized, manufacturers relocate production because of cheaper foreign labor. An FDIs-originating country moves from being a net exporter to a net importer.

The 1970s saw a more relevant attempt to explain FDIs by eclectic and synthetic theories. Dunning (1993) considers imperfect competition, comparative advantages and the internationalization of transaction costs as factors explaining FDIs.

The eclectic paradigm or the OLI paradigm emerged. It denotes the following three divisions: firm-specific advantages (O: "ownership"), country comparative advantages (L: "Location") and internalization advantages (I: "Internalization advantage"). This is what Dunning calls the three foundations behind the existence of multinational firms: "The (net) competitive advantages which firms of one nationality possess over those of another nationality in supplying any particular market or set of markets. These advantages may arise either from the firm's privileged ownership of or access to, a set of income-generating assets, or from their ability to coordinate these assets with other assets across national boundaries in a way that benefits them relative to their competitors, or potential competitors. The extent to which firms perceive it to be in their best interests to internalize the markets for the generation and/or the use of these assets; and by so doing add value to them. The extent to which firms choose to locate these value-adding activities outside their national boundaries $»^{3}$.

Dunning (1981) drew on several theories to formalize his "paradigm", but three of them form the main core. The first is the "Ownership approach" whose specific advantages refer to the competitive advantages of the firms seeking to engage in foreign direct investments. The greater the competitive advantages of the investing firms, the more they are likely to engage in foreign production. The second is the "Location approach" where FDIs are explained by the characteristics and advantages offered by the countries. The second is "Industrial organization", which claims that it is the search for

\footnotetext{
${ }^{3}$ Dunning (2001), "The Eelectic (OLI) Paradigm of International Production: Past, Present and Future”, International Journal of the Economics of Business, Vol. 8, No.2, pp. 176.
} 
oligopolistic or monopolistic positions that motivates firms to become multinationals. The third is the "Internalization approach", which shows that it is in the interest of companies to opt for internalization as a way of organizing their production in order to avoid the high transaction costs of the market.

The synthetic approach re-establishes the three levels of analysis more distinctly than the eclectic approach does. Blomström et al (2003) adopt the notion of competitive advantages proposed by Porter (1990). According to Porter (1990), competitive advantages may originate from the reduction of production costs (technological innovations or factor costs) and product differentiation (brands, advertising, monopolistic competition). Blomström et al (2003) combine the notion of competitive advantages with the notion of comparative advantages, which includes the notion of locational advantages. According to Blomström et al (2003), the concept of comparative advantages is broadened to take into account not only comparative costs but also comparative advantages in terms of size and demand dynamics.

The principle of Blomström et al (2003)'s approach is a simple combination of these two advantages. The firm needs a quantity of inputs to produce a good. For it to be competitive, it should seek these factors at the best costs. For its part, the country offers production factors with a quantity and quality that depends on its output and on consumer demand for goods. Blomström et al (2003) state "A kind of concordance or discordance will be established between these two types of advantages, between the firm and the conditions found in its country of origin". According to the authors, given that there are two scenarios (advantage or disadvantage) that can be experienced by the variables product and factor supply and demand, there is a possibility of concordance or discordance. It is the match or mismatch between the types of advantages that will determine whether the firm will export or relocate.

Foreign direct investment can take place when the domestic firm invests abroad, to the extent that it will find both cheaper inputs and greater markets for its products. This is the case of outward FDIs. When FDIs are incoming, the reverse process takes place, the foreign firm invests in the national country.

Despite the wealth of literature dealing with the determinants of FDIs, the difficulty in measuring the quality of institutions has generally diverted attention from the concept of institutional adaptation. There is a growing body of literature that has addressed the challenges of implementing FDIs policies and strategies. Thus, developing institutional adaptation is now the objective pursued by a number of organizations in this field. The study of the relationship between FDI inflows and adaptation to FDI highlights the micro-determinants over macro-determinants. The reason for this perspective is that when country-level determinants discourage FDIs, firm-level determinants matter less.

The "Environment, System, Politics" (ESP) approach of Koopman \& Montias (1971) claims that FDIs depend on the evolution of a country's structural variables, i.e. the interconnection between the environment (natural, human and infrastructure resources), the system (political, economic and social institutions) and politics (actions taken by governments). However, despite the efforts made, the general context in developing countries does not necessarily ensure these conditions. Corruption, the non-enforcement of laws and regulations by civil society and the inefficiency of the judicial system are obstacles that reflect the dysfunctioning and inefficiency of institutions in these countries and delay the implementation of economic reforms, thereby discouraging investors.

FDI inflows targeting the macroeconomic level are the subject of decisions taken at the microeconomic level of firms, depending on the expected returns of an investment. Thus, the policy environment is a key determinant of investment decisions, which directly affects foreign-owned firms. Unwilling to suffer a loss in profits caused by poetic disturbances, firms favor stable host countries. The country's future should be predictable enough for MNCs to assess the profitability of projects across other comparable destinations. Beyond the variables representing a generally favorable business environment, MNCs are concerned with political and economic stability. It is difficult to separate the two. Economic stability cannot be ensured in a climate of high political tensions. On the other hand, political stability does not necessarily imply economic stability. To attract FDIs, countries should actively rather than passively seek to protect local industries and natural resources.

Adaptation refers to a skill that needs to be developed and exercised regularly. In other words, it is not the largest countries that succeed in attracting more FDIs, but rather those that are best adapted. Saskia \& Stanley (1998) argue that "the countries that succeed best are those that are flexible enough to bend with the wind while their competitive advantage provides them with firm roots to secure themselves and branch out". Some small countries, which seemed to be at a disadvantage in terms of resources, nevertheless attracted large FDI inflows. Others with abundant raw materials reserves received much less FDIs than these reserves seemed to indicate. Institutional adaptation theory of FDIs explains why the distribution of FDI inflows is so uneven and often out of proportion to countries' natural resources. Hence the ability to recognize and take advantage of FDI opportunities is embedded in the country's institutions, which explains the term institutional adaptation to FDIs. 


\section{Data and Models Specifications}

The independent variables fall into three categories, (1) a set of variables that represent public governance quality ${ }^{4}$; (2) a set of variables that represent physical infrastructure quality; and (3) a set of variables represent macroeconomic policies quality.

The first set of variables consists of six governance indicators. Multiplicity of indicators is explained by the complex and multidimensional nature of governance: (1) Corruption Control (CC): This indicator measures the use of power prerogatives for personal gain, in particular the enrichment of individuals in positions of power; (World Bank Institute, WBI); (2) Capacity for Public Action (CAPPUB): this is a measure of the competence of public administration and the public services quality; (World Bank Institute, WBI); (3) Political Stability and Violence (PS): this indicator measures the likelihood of a violent regime or government changes, as well as serious threats to public order, including terrorism. The higher the PS indicator, the greater political stability; (World Bank Institute, WBI); (4) Legal Procedures Quality (Rule of Law or RL): This indicator measures the quality of compliance with legal contracts by the judiciary or the police, taking into account the use of private violence and its repression; (World Bank Institute, WBI); (5)Regulation Quality (RQ): this indicator measures regulatory obstacles to the functioning of markets; (World Bank Institute, WBI); and (6) Voice and Accountability (VA): This indicator measures the political and individual rights enjoyed by citizens (World Bank Institute, WBI).

The second set of variables includes the Life expectancy at birth, LIFEE: can be seen as an indicator of health system quality (World Bank, World Development Indicators). Gross secondary school enrolment ratio, HK: indicates human capital quality; (World Bank, World Development Indicators). Total population, POP; (World Bank, World Development Indicators). Number of fixed telephone lines per 1000 inhabitants, INFR: indicates the quality of physical infrastructure; (World Bank, World Development Indicators).

The third set of variables includes the OR openness rate defined by $\frac{\text { exports+imports }}{G D P}$ (World Bank, World Development

Indicators). Government expenditure/GDP, GOVE: weight of the State in the economy (World Bank, World Development Indicators). FDI inflows of the previous year, FDI $_{\text {it-1 }}$ (World Bank, World Development Indicators). Income/real capita, GDPH; (World Bank, World Development Indicators).

The basic equation is as follows:

$$
\begin{gathered}
\ln (F D I / G D P)_{i t}=\alpha_{i}+\beta_{1} C C_{i t}+\beta_{2} G E_{i t}+\beta_{3} P S_{i t}+\beta_{4} R L_{i t}+\beta_{5} R Q_{i t}+\beta_{6} V A_{i t}+\beta_{7} L I F E E_{i t} \\
+\beta_{8} H K_{i t}+\beta_{9} L n P O P T_{i t}+\beta_{10} L_{n I N F R_{i t}}+\beta_{11} O R_{i t}+\beta_{12} L n G O V E_{i t}+\beta_{13} L n F D I_{i t-1} \\
+\beta_{14} L n G D P C_{i t}+\varepsilon_{i t}
\end{gathered}
$$

Country $\mathrm{i}, \mathrm{i} \in[1, \mathrm{~N}]$; year $\mathrm{t}, \mathrm{t} \in[1,10]$ from 2008 to 2017 ; variable $\mathrm{k}, \mathrm{k} \in[1, \mathrm{~K}] ; \varepsilon_{i t}$ is error term. The specification of our model is inspired by that of Globerman \& Shapiro (2003). In the basic specification of the model, FDI inflows, total population, share of government expenditure and GDP per capita are measured in logarithms. GDP per capita coefficient measures elasticity of FDI inflows. Given the level of GDP per capita, a country's attractiveness to foreign investors will depend on the extent and nature of its infrastructure and quality of life. There are other specifications that the basic equation considers and tests. In particular, we have estimated models where the dependent variable is inward and outward FDIs. The term Ln (GDP per capita) is not included among the independent variables. This specification was rejected because the dependent variable is usually clustered in a narrow range; this narrow variation produces very unreliable parameter estimates and limited explanatory power with the ordinary least squares method. This specification produced results similar to those described below. In fact, there is almost no difference in the level of significance of the independent variables, and the use of this specification does not alter our conclusions. We also estimated models where the dependent variable is the proportion of overall FDIs received by a country. These measures show a high correlation with the variable $\mathrm{Ln} \mathrm{FDI}_{\mathrm{it}-\mathrm{l}}$, indicating some indifference as to the choices to be made between the variables. Therefore, we present only the results of the log (natural) specification, where GDP per capita is also expressed in natural logarithms. This specification offers more flexibility because it allows for estimating FDI elasticity with respect to GDP per capita and includes as an independent variable the lagged measure of FDI $_{\mathrm{it}-1}$.

For the independent variables, the final specification was estimated by removing all the control variables that were not

\footnotetext{
4 These indicators are constructed by the World Bank Institute team: Kaufmann D., Kraay A., and Zoidi-Lobaton O; known by the $\mathrm{KKZ}$ indicators of public governance.
} 
statistically significant in the preliminary estimates or those that show extreme multicollinearity. As noted earlier, few of the control variables for which data were available were found to be statistically significant, with the exception of GDP per capita. Note that GDP per capita is already part of the Human Development Index (HDI). Standard F-tests indicate that this model is preferable to others which also include the control variables discussed above.

We finally retain 4 families of models. For each group of CEECs and SEMCs, we will have two scenarios: the first with the 6 disaggregated governance indicators and the second with a single synthetic governance indicator (GI) represented by the arithmetic mean of the disaggregated indicators. Tables 3, 4, 5 and 6 respectively report the results of the regressions.

Family CEECs 1

$$
\begin{aligned}
& \operatorname{Ln}(F D I / G D P)_{i t}=\alpha_{i}+\beta_{1} C C_{i t}+\beta_{2} C A P P U B_{i t}+\beta_{3} P S_{i t}+\beta_{4} R L_{i t}+\beta_{5} R Q_{i t}+\beta_{6} V A_{i t} \\
& +\beta_{7} L_{I F E E_{i t}}+\beta_{8} H K_{i t}+\beta_{9} \operatorname{LnPOP}_{i t}+\beta_{10} \operatorname{LnINFR}_{i t}+\beta_{11} O R_{i t}+\beta_{12} \operatorname{LnGOVE}_{i t}+ \\
& \beta_{13} L_{n F D I} I_{i t-1}+\beta_{14} \operatorname{LnGDPC}_{I T}+\varepsilon_{i t}
\end{aligned}
$$

Family CEECs 2

$$
\begin{gathered}
\operatorname{Ln}(F D I / G D P)_{i t}=\alpha_{i}+\beta_{1} G I_{i t}+\beta_{2} L_{I F E E_{i t}}+\beta_{3} H K_{i t}+\beta_{4} \operatorname{LnPOP}_{i t}+\beta_{5} \operatorname{LnINFR}_{i t}+ \\
\beta_{6} \mathrm{OR}_{i t}+\beta_{7} \operatorname{LnGOVE}_{i t}+\beta_{8} \operatorname{LnFDI}_{i t-1}+\beta_{9} L n G G D P C_{i t}+\varepsilon_{i t}
\end{gathered}
$$

Family SEMCs 1

$$
\begin{aligned}
& \operatorname{Ln}(F D I / G D P)_{i t}=\alpha_{i}+\beta_{1} C C_{i t}+\beta_{2} C A P P U B_{i t}+\beta_{3} P S_{i t}+\beta_{4} R L_{i t}+\beta_{5} R Q_{i t}+\beta_{6} V A_{i t} \\
& +\beta_{7} \text { LIFEE }_{i t}+\beta_{8} H_{i t}+\beta_{9} \text { LnPOP }_{i t}+\beta_{10} \operatorname{LnINFR}_{i t}+\beta_{11} O R_{i t}+\beta_{12} L_{n G O V E_{i t}}+ \\
& \beta_{13} L_{n F D I} I_{i t-1}+\beta_{14} \operatorname{LnGDPC} C_{I T}+\varepsilon_{i t}
\end{aligned}
$$

Family SEMCs 2

$$
\begin{gathered}
\operatorname{Ln}(F D I / G D P)_{i t}=\alpha_{i}+\beta_{1} G I_{i t}+\beta_{2} L I F E E_{i t}+\beta_{3} H K_{i t}+\beta_{4} L n P O P_{i t}+\beta_{5} L_{n I N F R_{i t}}+ \\
\beta_{6} O R_{i t}+\beta_{7} L_{n O V E}+\beta_{8} L_{i n} I_{i t-1}+\beta_{9} L n G D P C_{i t}+\varepsilon_{i t}
\end{gathered}
$$

\section{Empirical Results and Discussion}

\subsection{Correlations}

Despite the simplicity of the basic model, a problem arises from cross-correlation between the independent variables under study. In addition to correlation between governance and infrastructure variables presented in Tables 1 and 2, there is a correlation between Ln GDP/capita and HK $(r=0.93)$ and between Ln GDP/capita and LIFEE $(r=0.84)$ for the CEECs group and $(r=0.89)$ and $(r=0.85)$ for the SEMCs group, respectively. These correlations illustrate the potential difficulty of statistically identifying the influence of some infrastructure measures particular of FDI models that include traditional economic variables such as GDP per capita. It is difficult to say at what level the correlation could give rise to multicollinearity problems. If we adopt Klein's thumb rule that correlation between variables should be lower than that of the estimated equation, then a correlation of 0.7 or more between any pair of independent variables could be problematic. 
Table 1. CEECs correlation matrix

\begin{tabular}{lcccccccccccccc}
\hline & VA & PS & CAPPUB & RQ & RL & CC & LIFEE & HK & POP & INFR & OR & GOVE & FDI I 1 & GDPC \\
\hline VA & 1 & & & & & & & & & & & & & \\
PS & 0.89 & 1 & & & & & & & & & & & & \\
CAPPUB & 0.91 & 0.79 & 1 & & & & & & & & & & & \\
RQ & 0.73 & 0.94 & 0.87 & 1 & & & & & & & & & & \\
RL & 0.67 & 0.70 & 0.77 & 0.90 & 1 & & & & & & & & & \\
CC & 0.91 & 0.92 & 0.91 & 0.96 & 0.89 & 1 & & & & & & & & \\
LIFEE & 0.42 & 0.64 & 0.44 & 0.59 & 0.57 & 0.51 & 1 & & & & & & & \\
HK & 0.63 & 0.66 & 0.71 & 0.79 & 0.75 & 0.67 & 0.81 & 1 & & & & & & \\
POP & 0.55 & 0.67 & 0.66 & 0.91 & 0.58 & 0.71 & 0.73 & 0.80 & 1 & & & & & \\
& & & & & & & & & & & & & & \\
INFR & 0.79 & 0.59 & 0.77 & 0.64 & 0.69 & 0.74 & 0.79 & 0.94 & 0.84 & 1 & & & & \\
OR & 0.49 & 0.51 & 0.54 & 0.56 & 0.61 & 0.48 & 0.37 & 0.40 & 0.39 & 0.59 & 1 & & & \\
GOVE & 0.72 & 0.80 & 0.63 & 0.71 & 0.83 & 0.71 & 0.72 & 0.74 & 0.86 & 0.67 & 0.57 & 1 & & \\
FDIt-1 & 0.17 & 0.12 & 0.10 & 0.11 & 0.15 & 0.23 & 0.06 & 0.18 & 0.61 & 0.49 & 0.21 & 0.28 & 1 & \\
GDPC & 0.87 & 0.66 & 0.59 & 0.87 & 0.71 & 0.61 & 0.84 & 0.93 & 0.53 & 0.61 & 0.40 & 0.85 & 0.33 & 1 \\
& & & & & & & & & & & & & & \\
\hline
\end{tabular}

Table 2. SEMCs correlation matrix

\begin{tabular}{lcccccccccccccc}
\hline & VA & PS & CAPPUB & RQ & RL & CC & LIFEE & HK & POP & INFR & OR & GOVE & FDIt-1 & GDPC \\
\hline VA & 1 & & & & & & & & & & & & & \\
PS & 0.74 & 1 & & & & & & & & & & & & \\
CAPPUB & 0.87 & 0.78 & 1 & & & & & & & & & & & \\
RQ & 0.77 & 0.96 & 0.77 & 1 & & & & & & & & & & \\
RL & 0.72 & 0.81 & 0.87 & 0.91 & 1 & & & & & & & & & \\
CC & 0.94 & 0.91 & 0.93 & 0.91 & 0.94 & 1 & & & & & & & & \\
LIFEE & 0.57 & 0.71 & 0.62 & 0.69 & 0.77 & 0.71 & 1 & & & & & & & \\
HK & 0.72 & 0.65 & 0.78 & 0.83 & 0.79 & 0.77 & 0.90 & 1 & & & & & & \\
POP & 0.61 & 0.69 & 0.76 & 0.88 & 0.79 & 0.72 & 0.85 & 0.87 & 1 & & & & & \\
& & & & & & & & & & & & & & \\
INFR & 0.89 & 0.69 & 0.87 & 0.74 & 0.79 & 0.78 & 0.75 & 0.91 & 0.83 & 1 & & & & \\
OR & 0.59 & 0.61 & 0.65 & 0.59 & 0.71 & 0.59 & 0.47 & 0.62 & 0.61 & 0.67 & 1 & & & \\
GOVE & 0.74 & 0.79 & 0.73 & 0.76 & 0.85 & 0.81 & 0.82 & 0.64 & 0.66 & 0.67 & 0.58 & 1 & & \\
FDIt-1 & 0.07 & 0.17 & 0.11 & 0.08 & 0.16 & 0.16 & 0.19 & 0.21 & 0.44 & 0.46 & 0.17 & 0.20 & 1 & \\
GDPC & 0.86 & 0.77 & 0.63 & 0.80 & 0.79 & 0.67 & 0.85 & 0.89 & 0.57 & 0.69 & 0.70 & 0.88 & 0.53 & 1 \\
\hline
\end{tabular}

Given that the model cannot be applied only in a case of stationary variables, we made recourse to Im, Pesaran and Shin's [1997] Unit Root test, known as IPShin. The results reported in appendix 1 show that all the variables turned out to be stationary.

\subsection{Method and Tests}

The Ordinary Least Squares (LSD) estimator in the fixed effects model is called the Within estimator or the Least Square Dummy Variable (LSDV) estimator. The term Within is explained by the fact that this estimator takes into account the within-group variance of the variable. When considering a sample of panel data, first check the homogeneous or heterogeneous specification of the data generating process. Econometrically, this amounts to testing the equality of the coefficients of the model under study in the individual dimension. Econometrically, specification tests are about whether one can assume that the theoretical model under study is perfectly identical for all countries, or 
on the contrary whether there are country-specific characteristics.

Global homogeneity test:

First of all, we test the total homogeneity hypothesis: $H_{0}^{1}: \alpha_{\mathrm{k}, \mathrm{i}}=\alpha_{\mathrm{k}}, \mathrm{k} \in[0, \mathrm{~N}]$; with i the index of the country and $\mathrm{k}$ the index of the exogenous variable. Under this hypothesis $\left(H_{0}^{1}\right.$ therein), the Fischer statistics of $H_{0}^{1}$ test, denoted F1, is 3.8320. The software also indicates the number of degrees of freedom of this statistics. F1 statistics followed a Fischer with $(\mathrm{N}-1)(\mathrm{K}+1)$ and $\mathrm{NT}-\mathrm{N}(\mathrm{K}+1)$ degrees of freedom. Given the size of our panel $(\mathrm{N}=11$, and $\mathrm{T}=10)$ and the number of independent variables $(K=8)$, we have therefore to tabulate the value of this coefficient with the Fischer $\mathrm{F}$ threshold $(81 ; 1)$. In our case, this statistics is very much lower than the threshold of 5\%. Therefore, with this threshold, we reject the null hypothesis $H_{0}^{1}$ of equality of constants and coefficients $\alpha_{\mathrm{k}, \mathrm{i}}$ : the Fischer statistic of this test shows that the model is not globally homogeneous. The hypothesis of total homogeneity is therefore rejected. It is then necessary to test whether the coefficients of the different independent variables are identical. If this is not the case, there is a priori no common modelling structure between countries. In this case, the use of panel data is not justified and may even lead to estimation biases. One should therefore estimate the models on a country-by-country basis. If it turns out that there is indeed an identical relationship between the dependent variable and the independent variables for all countries, the source of model heterogeneity may then come from the constants.

Homogeneity test $\alpha_{k, i}=\alpha ; k$ and $i \in[1, N]$

Let us now test homogeneity of the coefficients under the null hypothesis, no restrictions are imposed on the individual constants $\alpha_{0, \text { i. }}$ Always, under the hypothesis of independence and normality of the residuals, a Fischer statistics is designed to test these $(\mathrm{N}-1) \mathrm{K}$ linear restrictions.

Homogeneity test $\alpha_{0, i}=\alpha_{0}, \quad i \in[1, N]$

The estimation results presented in Tables 3, 4, 5 and 6 accept the Ho hypothesis of homogeneity of constants.

Error autocorrelation test

As for inter-individual autocorrelation (contemporaneous correlation), the Breusch-Pagan test accepts the Ho hypothesis of independence of residuals between individuals. The intra-individual residuals autocorrelation test of Wooldridge (2002) confirms the absence of serial autocorrelation in the model because the Ho hypothesis of independence of the residuals is not to be rejected. 
Table 3. CEECs1 family: Six indicators of public governance/dependent variable (FDI/GDP)

\begin{tabular}{|c|c|c|c|c|}
\hline Variables & $\begin{array}{c}\text { Model } \\
\text { (CEECs 1.1) }\end{array}$ & $\begin{array}{c}\text { Model } \\
\text { (CEECs 1.2) }\end{array}$ & $\begin{array}{c}\text { Model } \\
\text { (CEECs 1.3) }\end{array}$ & $\begin{array}{c}\text { Model } \\
\text { (CEECs 1.4) }\end{array}$ \\
\hline \multirow[t]{2}{*}{ CONST } & 0.993 & 1.385 & $1.017 *$ & 0.968 \\
\hline & $(0.043)$ & $(0.196)$ & (1.566) & (1.492) \\
\hline \multirow[t]{2}{*}{ VA } & 0.001 & 0.001 & 0.003 & 0.002 \\
\hline & $(0.517)$ & $(0.230)$ & $(0.336)$ & $(0.322)$ \\
\hline \multirow[t]{2}{*}{ PS } & $0.172 * * *$ & $0.244 * * *$ & $0.628 * * *$ & $0.171 * * *$ \\
\hline & $(2.562)$ & $(3.296)$ & $(2.634)$ & $(3.269)$ \\
\hline \multirow[t]{2}{*}{ CAPPUB } & 0.070 & 0.021 & 0.031 & 0.031 \\
\hline & $(0.762)$ & $(0.303)$ & $(0.08)$ & $(0.160)$ \\
\hline \multirow[t]{2}{*}{ RQ } & $0.229 * * *$ & $0.409 * * *$ & $0.435^{* * *}$ & $0.447 * * *$ \\
\hline & $(2.347)$ & $(2.154)$ & $(2.373)$ & $(2.309)$ \\
\hline \multirow[t]{2}{*}{ RL } & 0.134 & $0.165^{*}$ & $0.165^{*}$ & $0.172 * * *$ \\
\hline & $(0.947)$ & (1.528) & (1.548) & $(2.817)$ \\
\hline \multirow[t]{2}{*}{$\mathrm{CC}$} & 0.074 & 0.084 & 0.057 & 0.092 \\
\hline & $(0.069)$ & $(0.122)$ & $(0.334)$ & $(0.213)$ \\
\hline \multirow[t]{2}{*}{ LIFEE } & 0.263 & $0.305^{* *}$ & 0.309 & $0.351 * *$ \\
\hline & (1.353) & (1.682) & (1.124) & $(1.850)$ \\
\hline \multirow[t]{2}{*}{ HK } & 0.064 & 0.021 & 0.014 & 0.063 \\
\hline & $(0.306)$ & $(0.051)$ & $(0.182)$ & $(0.405)$ \\
\hline \multirow[t]{2}{*}{ POP } & $0.1528 * *$ & $0.195^{* * *}$ & 0.2536 & $0.353^{*}$ \\
\hline & $(1.915)$ & $(2.426)$ & (1.308) & (1.798) \\
\hline \multirow[t]{2}{*}{ INFR } & & $0.067 * * *$ & & $0.097 * * *$ \\
\hline & & $(2.071)$ & & $(3.477)$ \\
\hline \multirow[t]{2}{*}{ OR } & & 0.070 & & 0.182 \\
\hline & & $(0.460)$ & & $(0.394)$ \\
\hline \multirow[t]{2}{*}{ GOVE } & & & 0.003 & $0.007 * * *$ \\
\hline & & & $(0.824)$ & $(2.391)$ \\
\hline \multirow[t]{2}{*}{$\mathrm{FDI}_{\mathrm{t}-1}$} & & & 0.119 & 0.190 \\
\hline & & & (1.531) & (1.479) \\
\hline \multirow[t]{2}{*}{ GDPC } & & & & 0.090 \\
\hline & & & & (1.019) \\
\hline$\overline{\mathrm{R} 2}$ & 0.716 & 0.760 & 0.730 & 0.761 \\
\hline $\mathrm{N}$ obs. & 99 & 99 & 99 & 99 \\
\hline
\end{tabular}

* significant at the .10-level, ** significant at the .05-level, *** significant at the .01-level. 
Table 4. Family CEECs2: Dependent Variable (FDI/GDP)

\begin{tabular}{|c|c|c|c|c|}
\hline Variables & Model (CEECs2.1) & Model (CEECs2.2) & Model (CEECs2.3) & Model (CEECs2.4) \\
\hline CONST & $\begin{array}{l}-3.867 * * \\
(-1.802)\end{array}$ & $\begin{array}{c}2.471 \\
(0.297)\end{array}$ & $\begin{array}{c}4.09 \\
(0.947)\end{array}$ & 4.26 \\
\hline GI & $\begin{array}{l}-0.140 * * \\
(-1.853)\end{array}$ & $\begin{array}{l}-0.027 \\
(-1.332)\end{array}$ & $0.126^{*}$ & $0.260 * * *$ \\
\hline LIFEE & $\begin{array}{l}0.045^{* *} \\
(1.796)\end{array}$ & $\begin{array}{l}0.065 \\
(1.246)\end{array}$ & $\begin{array}{l}0.080 * * * \\
(2.705)\end{array}$ & $\begin{array}{c}0.102 * * * \\
(6.130)\end{array}$ \\
\hline HK & $\begin{array}{l}0.005 \\
(0.643)\end{array}$ & $\begin{array}{c}0.012 \\
(0.484)\end{array}$ & $\begin{array}{c}0.011 \\
(0.610)\end{array}$ & $\begin{array}{c}0.073 \\
(0.908)\end{array}$ \\
\hline POP & $\begin{array}{c}0.081 \\
(1.516)\end{array}$ & $\begin{array}{l}0.131^{*} \\
(1.760)\end{array}$ & $\begin{array}{c}0.023 \\
(0.898)\end{array}$ & $\begin{array}{c}0.217 * * * \\
(3.626)\end{array}$ \\
\hline INFR & & $\begin{array}{c}0.009 \\
(1.633)\end{array}$ & $\begin{array}{l}0.089^{* *} \\
(1.712)\end{array}$ & \\
\hline OR & & $\begin{array}{c}0.010 \\
(0.120)\end{array}$ & & $\begin{array}{c}0.012 \\
(1.225)\end{array}$ \\
\hline GOVE & & & $\begin{array}{c}0.244 * * \\
(1.981)\end{array}$ & $\begin{array}{c}0.074 \\
(0.568)\end{array}$ \\
\hline $\mathrm{FDI}_{\mathrm{t}-1}$ & & & $\begin{array}{c}0.112 \\
(0.984)\end{array}$ & $\begin{array}{l}0.259^{*} \\
(1.705)\end{array}$ \\
\hline GDPC & & & & $\begin{array}{c}0.401 * * * \\
(3.035)\end{array}$ \\
\hline $\begin{array}{l}\overline{\mathrm{R} 2} \\
\mathrm{~N} \text { obs. }\end{array}$ & $\begin{array}{l}0.726 \\
99\end{array}$ & $\begin{array}{l}0.763 \\
99\end{array}$ & $\begin{array}{l}0.738 \\
99\end{array}$ & $\begin{array}{l}0.766 \\
99\end{array}$ \\
\hline
\end{tabular}

* significant at the .10-level, ** significant at the .05-level, *** significant at the .01-level.

Table 5. Family SEMCs1: Six indicators of public governance/dependent variable (FDI/GDP)

\begin{tabular}{lcccc}
\hline Variables & $\begin{array}{c}\text { Model } \\
\text { (SEMCs1.1) }\end{array}$ & $\begin{array}{c}\text { Model } \\
\text { (SEMCs1.2) }\end{array}$ & $\begin{array}{c}\text { Model } \\
\text { (SEMCs1.3) }\end{array}$ & $\begin{array}{c}\text { Model } \\
\text { (SEMCs1.4) }\end{array}$ \\
\hline CONST & $-1.648^{* *}$ & 0.510 & 3.696 & 3.281 \\
& $(-1.910)$ & $(0.369)$ & $(0.099)$ & $(1.186)$ \\
VA & 0.079 & 0.067 & 0.074 & 0.063 \\
& $(0.518)$ & $(0.091)$ & $(0.781)$ & $(0.454)$ \\
PS & 0.084 & 0.038 & 0.148 & 0.148 \\
& $(0.872)$ & $(0.490)$ & $(0.026)$ & $(0.545)$ \\
CAPPUB & -0.083 & 0.050 & 0.124 & 0.132 \\
& $(-0.616)$ & $(0.456)$ & $(0.951)$ & $(0.652)$ \\
RQ & 0.023 & 0.056 & 0.092 & 0.037 \\
& $(0.095)$ & $(0.621)$ & $(1.390)$ & $(0.281)$ \\
RL & 0.008 & 0.008 & 0.041 & 0.081 \\
& $(0.682)$ & $(1.601)$ & $(0.502)$ & $(0.826)$ \\
CC & 0.045 & 0.054 & -0.185 & 0.156 \\
& $(0.629)$ & $(0.562)$ & $(-1.103)$ & $(1.175)$ \\
LIFEE & 0.061 & 0.067 & 0.041 & 0.088 \\
& $(0.043)$ & $(0.157)$ & $(0.791)$ & $(0.750)$ \\
HK & 0.087 & 0.016 & 0.173 & 0.127 \\
& $(0.285)$ & $(0.128)$ & $(0.151)$ & $(0.747)$ \\
POP & 0.049 & 0.031 & $0.076 *$ & $0.048 *$ \\
& $(1.153)$ & $(1.324)$ & $(1.725)$ & $(1.734)$ \\
INFR & & 0.011 & & 0.090 \\
& & $(2.717)$ & & $(2.105)$ \\
OR & & $0.137 * *$ & & 0.095 \\
& & $(1.976)$ & & $(1.03)$ \\
GOVE & & & $0.038^{* * * *}$ & $0.035^{* * *}$ \\
& & & $(4.754)$ & $(4.348)$ \\
FDI & & & $0.0128^{*}-1 * *$ & $0.018^{* * *}$ \\
& & & $(2.563)$ & $(2.598)$ \\
GDPC & & 0.676 & & $0.018 * *$ \\
& & 110 & 0.717 & $(1.998)$ \\
R2 & & 110 & 0.729 \\
N obs. & 0.652 & & 110 \\
\hline
\end{tabular}

* significant at the .10-level, ** significant at the .05-level, *** significant at the .01-level. 
Table 6. Family SEMCs2: Dependent Variable (FDI/GDP)

\begin{tabular}{lcccc}
\hline Variables & $\begin{array}{c}\text { Model } \\
\text { (SEMCs2.1) }\end{array}$ & Model (SEMCs2.2) & $\begin{array}{c}\text { Model } \\
\text { (SEMCs2.3) }\end{array}$ & $\begin{array}{c}\text { Model } \\
\text { (SEMCs2.4) }\end{array}$ \\
\hline CONST & $-8.443^{* * *}$ & -8.074 & 4.891 & 3.90 \\
GI & $(-2.397)$ & $(-0.071)$ & $(0.073)$ & $(1.264)$ \\
& 0.091 & 0.018 & $0.141^{* * *}$ & $0.132^{* * *}$ \\
LIFEE & $(1.369)$ & $(1.124)$ & $(2.605)$ & $(4.232)$ \\
& $0.056^{* *}$ & $0.040^{* *}$ & $0.079^{*}$ & $0.172^{*}$ \\
HK & $(2.146)$ & $(2.096)$ & $(1.709)$ & $(1.791)$ \\
& 0.076 & 0.059 & 0.161 & 0.115 \\
POP & $(0.197)$ & $(0.701)$ & $(0.223)$ & $(0.972)$ \\
& 0.024 & 0.025 & $0.124^{* *}$ & $0.223^{* * *}$ \\
INFR & $(1.246)$ & $(1.489)$ & $(2.004)$ & $(2.853)$ \\
& & $0.005^{* *}$ & $0.044^{* *}$ & \\
OR & & $(1.969)$ & $(1.931)$ & $0.003^{* * * *}$ \\
& & $0.001^{*}$ & & $(2.423)$ \\
GOVE & $(1.719)$ & $0.034^{* * *}$ \\
& & & $0.035^{* * *}$ & $(4.642)$ \\
FDI & & & $(4.732)$ & 0.645 \\
& & & 0.096 & $(1.605)$ \\
GDPC & & & $(1.567)$ & $0.141^{* * *}$ \\
& & & & $(3.85)$ \\
& & & & 0.770 \\
R2 & & 0.716 & 0.759 & 110 \\
N obs. & 0.700 & 110 & 110 & \\
\hline
\end{tabular}

$*$ significant at the .10-level, ** significant at the .05-level, *** significant at the .01-level.

\subsection{Discussion of the Results}

In Table 3, the significant determinants of public governance variables are political stability (PS), regulatory quality (RQ), and quality of legal procedures (RL). This result confirms the findings of Masron (2017) and Fragkiskos et al. (2019). The corruption control variable (CC) shows positive but low and insignificant values in the different models of the CEECs 1 family, which may explain the skeptical relationship between inward FDIs and corruption in transition countries.

For the physical infrastructure variables, as proved by Carp (2014) and Saini \& Singhania (2018) the most significant variables are respectively the infrastructure variable (INFR), and total population (POP). Human capital (HK) and per capita income (GDPC) variables show positive but insignificant coefficients. As for the variables representing to macroeconomic policies quality, the only statistically significant variable is public expenditure (GOVE). The other variables show positive but insignificant coefficients in all specifications.

The results in Table.4 for the CEECs 2 family show better results with more significant coefficients of the different sets of variables. The composite index of the governance variable (GI) shows positive and significant coefficients. Similarly, same as Jimborean \& Kelber (2017) and Mihaylova (2020), the variables representing physical infrastructure show positive and statistically significant coefficients. On the other hand, only the openness degree (OR) variable remains insignificant. The results of the regressions of the CEECs show that entrepreneurs invest in this region mainly for governance quality and infrastructure quality. This results confirms the findings of Alfalih \& Bel Hadj (2020) that indicate that the size of markets, the real exchange rate, and law and order have positive effects on FDI, over short- and long-run periods. Macroeconomic policy variables seem to attract less FDIs to these countries.

For the control variables, our results also show that the gross domestic product per capita (GDPC) variable is statistically significant. On the other hand, the results show a weak role of the agglomeration effect with low values of the coefficient of the $\mathrm{FDI}_{\mathrm{t}-1}$ variable.

In Table. 5, the regression results of SEMCs 1 family show that the governance variables have positive, low and non-significant coefficients. Human capital quality also has positive but non-significant coefficients. In line with Elheddada (2019) and Adhikary (2017) for physical infrastructure variables, total population and infrastructure show positive and statistically significant coefficients. Similarly, macroeconomic policy variables also show positive and significant coefficients. 
On the other hand, the results in Table. 6 of SEMCs 2 show that the governance variable becomes statistically significant but keeps a low value. The other variables of physical infrastructure and macroeconomic policies seem more robust and better explain FDI inflows to this region. In order to measure the role of human capital (HK), skilled labor does not yet seem to be an important determinant for foreign investors. This finding is in line with that of Sekkat and Véganzones-Varoudakis (2004), Mgadmi \& Moussa (2018) and Alkathiri \& Soliman (2020) for the MENA region, Compos \& Kinoshita (2003) for CEECs, but also Cheng and Kwan (2000) for the Chinese region. In line with Oroa \& Alagidedeb (2021), for the control variables, our results also show that the gross domestic product per capita (GDPC) variable is statistically significant. European entrepreneurs are much more interested in the market than in the dynamism of the region.

\section{Conclusion}

The development of a real strategy to attract foreign direct investments to CEECs and SEMCs needs an in-depth understanding of the determining factors of such an endeavor. This paper addressed this issue by examining three categories of determinants. The first one includes a series of variables that represent public governance quality. The second category groups a series of variables representing physical infrastructure quality. The third includes a series of variables representing macroeconomic policies quality. Our panel estimates show that the first set of variables of public governance, in particular political stability (PS), regulation quality (RQ), and legal procedures quality (LR) explain well FDI inflows to CEECs. The corruption control variable (CC) shows positive but low and insignificant coefficients. This may explain the skeptical relationship between inward FDIs and corruption in transition countries. Public governance variables are positive but not significant in the first SEMCs family regressions. In the second SEMCs family regressions, the public governance composite variable becomes positive and statistically significant.

The estimates of the second set of variables show positive and significant effects for both groups of variables, particularly population and infrastructure. These results show the horizontal layout of the international investment strategy towards these two regions. The estimates also show a weaker role of macroeconomic policies, with the exception of public expenditure, which shows positive coefficients.

CEECs and SEMCs regions have many similarities, especially the progress made in the institutional field. Such a similarity is linked to the transition and then accession programs to the European Union for the CEECs, and the IMF-supervised structural adjustment programs for the SEMCs. Similarly, these two groups of countries, despite their intra-heterogeneity in terms of human capital and population, have several other similarities, such as physical infrastructure quality, economic openness and the geographical proximity to Europe.

The empirical results show that the two regions are substitutable in terms of international investment attractiveness. Public governance is an asset for attracting the long-term productive investment necessary for these countries to reach an economic take-off, following the example of South-East Asian countries or some Latin American countries. Governments in both CEECs and SEMCs need to continue their achievements and progress in good governance, in particular tackling corruption at all levels.

\section{References}

Adhikary, B. K. (2017). Factors influencing foreign direct investment in South Asian economies, A comparative analysis. South Asian Journal of Business Studies, 6(1), 8-37. https://doi.org/10.1108/SAJBS-10-2015-0070

Alfalih, A. A., \& Bel Hadj, T. (2020). Foreign direct investment determinants in an oil abundant host country: Short and long-run approach for Saudi Arabia. Resources Policy, 66, 1-11. https://doi.org/10.1016/j.resourpol.2020.101616

Aliber, R. Z. (1970). A Theory of Direct Foreign Investment, in Kindleberger C. (ed), The International Corporation, MIT Press, Cambridge Mass.

Alkathiri, N. A., \& Soliman, M. (2020). Examining foreign direct investment determinants of tourism industry in Oman and Egypt: The moderating role of investment environment, International Journal of Finance \& Economics. https://doi.org/10.1002/ijfe.2396

Blomström, M., Kokko, A., \& Mucchielli, J. L. (2003). The economics of foreign direct investment incentives, Foreign direct investment in the real and financial sector of industrial countries. Springer, Berlin, Heidelberg. https://doi.org/10.3386/w9489

Campos, N., \& Kinoshita, Y. (2003). Why Does FDI Go Where it Goes? New Evidence from the Transition Economies, IMF Working Paper No.03/228. https://doi.org/10.5089/9781451875461.001

Carp, L. (2014). Determinants of foreign direct investments in Romania. Practical Application of Science, II, 3(5).

Caves, R. E. (1971). International corporations: The industrial economics of foreign investment. Economica, 38, 149. https://doi.org/10.2307/2551748 
Cheng, L. K., \& Kwan, Y. K. (2000). What are the Determinants of the Location of Foreign Direct Investment? The Chinese Experience. Journal of International Economics, 51(2), 379-400. https://doi.org/10.1016/S0022-1996(99)00032-X

Dunning, J. H. (1981). International Production and the Multinational Enterprise. George Allen and Unwin, London.

Dunning, J. H. (1993). Multinational Enterprises and the Global Economy. Wokingham, Addison Wesley.

Dunning, J. H. (2001). The Eclectic (OLI) Paradigm of International Production: Past, Present and Future. International Journal of the Economics of Business, 8(2). https://doi.org/10.1080/13571510110051441

Elheddada, M. (2019). Foreign direct investment and domestic investment: Do oil sectors matter? Evidence from oil-exporting Gulf Cooperation Council. Journal of Economics and Business, 103, 1-12. https://doi.org/10.1016/j.jeconbus.2018.11.001

Fragkiskos, F., Annan-Diab, F., Hermidas, A., \& Theodoraki, C. (2019). Political governance, civil liberties, and human capital: Evaluating their effect on foreign direct investment in emerging and developing economies. Journal of International Business Studies, 50, 1103-1129. https://doi.org/10.1057/s41267-019-00239-3

Globerman, S., \& Shapiro, D. (2003). Governance infrastructure and US foreign direct investment. Journal of International Business Studies, 34, 19-39. https://doi.org/10.1057/palgrave.jibs.8400001

Hall, R. E., \& Jones, C. I. (1999). Why do some countries produce so much more output per worker than others? Quarterly Journal of Economics, 114(1), 83-116. https://doi.org/10.1162/003355399555954

Hirsch, S. (1976). An International Trade and Investment Theory of the Firm. Oxford Economic Papers, 28(2), 258-70. https://doi.org/10.1093/oxfordjournals.oep.a041344

Hymer, S. (1960). The International Operations of National Firms: A Study of Direct Foreign Investment. The MIT Press, Cambridge.

Im, Kyung So, Hashem, M. P., \& Shin, Y. (1997). Testing for Unit Roots in Heterogeneous Panels. University of Cambridge Working Paper No. 9526.

Jimborean, R., \& Kelber, A. (2017). Foreign Direct Investment Drivers and Growth in Central and Eastern Europe in the Aftermath of the 2007 Global Financial Crisis. Comparative Economic Studies, 59, 23-54. https://doi.org/10.1057/s41294-016-0018-9

Kaufmann, D., Kraay, A., \& Zoido-Lobaton, P. (1999). Aggregating governance indicators. World Bank Policy Research, Working Paper, 2196. Washington DC: World Bank Institute. https://doi.org/10.2139/ssrn.188548

Kindleberger, C. P. (1969). American Business Abroad. Yale University Press, New Haven, CT, United States. https://doi.org/10.1002/tie.5060110207

Knack, S., \& Keefer, P. (1995). Institutions and economic performance: Cross-country tests using alternative institutional measures. Economics and Politics, 7, 207-227. https://doi.org/10.1111/j.1468-0343.1995.tb00111.x

Kojima, K. (1973). A Macroeconomic Approach to Foreign Direct Investment. Hitotsubashi Journal of Economics, Vol. 14 (June).

Koopman, K., \& Montias, J. M. (1971). On the description and comparison of economic systems. In A. Eckstein (Ed.), Comparison of economic systems:Theoretical and methodological approaches. Berkeley,CA: University of California Press. Leonar.

Masron, T. A. (2017). Relative institutional quality and FDI inflows in ASEAN countries. Journal of Economic Studies, 44(1), 115-137. https://doi.org/10.1108/JES-04-2015-0067

Mgadmi, N., \& Moussa, W. (2018). The impact of governance on FDI attractiveness: the MENA countries case. Journal of Academic Research in Economics, 10(3), 466-481.

Mihaylova, S. (2020). Foreign Direct Investment Attractiveness of Central, Eastern, and Southeastern European Countries: The Importance of Policy-Related Location Advantages. Croatian Economic Survey, 22(1), 65-101. https://doi.org/10.15179/ces.22.1.3

Oroa, O. U., \& Alagidedeb, I. P. (2021). Does petroleum resources or market size drive foreign direct investment in Africa? New evidence from time-series analysis. Resources Policy, 71, 1-8. https://doi.org/10.1016/j.resourpol.2021.101992

Porter, M. E. (1990). The competitive advantage of nations. London: Macmillan. https://doi.org/10.1007/978-1-349-11336-1 
Saini, N., \& Singhania, M. (2018). Determinants of FDI in developed and developing countries: a quantitative analysis using GMM. Journal of Economic Studies, 45(2), 348-382. https://doi.org/10.1108/JES-07-2016-0138

Saskia K. S., Stanley, W. M. (1998). Foreign Direct investment and its determinants in emerging economies, African Economic Policy Paper Discussion Paper No. 9, Funded by United States Agency for International Development Bureau for Africa Office of Sustainable Development Washington, D.C. 20523-4600.

Sekkat, K., \& Veganzones-Varoudakis, M. A. (2004). Trade and Foreign Exchange Liberalization, Investment Climate and FDI in the MENA Countries, DULBEA, Université Libre de Bruxelles, Working paper n.05.06.

Vernon, R. (1966). International investment and international trade in the product cycle. Quarterly Journal of Economics, 80(2). https://doi.org/10.2307/1880689

Wooldridge, J. M. (2002). Econometric Analysis of Cross Section and Panel Data, Cambridge: MIT press.

Appendix 1.Unit Root Tests

\begin{tabular}{lcc}
\hline Variables & $\mathrm{t}-$ Stat & Prob \\
\hline VA & -4.5175 & 0.0003 \\
PS & -4.3461 & 0.0005 \\
CAPPUB & -5.3063 & 0.0000 \\
RQ & -6.2096 & 0.0000 \\
RL & -6.5544 & 0.0000 \\
CC & -2.6418 & 0.0866 \\
LIFEE & -5.7342 & 0.0000 \\
HK & -6.5757 & 0.0000 \\
POP & -2.2814 & 0.1791 \\
INFR & -3.446 & 0.0000 \\
OR & -4.112 & 0.0000 \\
GOVE & -3.3596 & 0.0000 \\
FDI & -3.3293 & 0.0287 \\
GDPC & -3.4695 & 0.0218 \\
\hline
\end{tabular}

\section{Copyrights}

Copyright for this article is retained by the author(s), with first publication rights granted to the journal.

This is an open-access article distributed under the terms and conditions of the Creative Commons Attribution license (http://creativecommons.org/licenses/by/4.0/). 